\title{
The prophylactic effect of Ranunculus laetus (Wall)-mediated silver nanoparticles against some Gram-positive and Gram-negative bacteria
}

\author{
Shah Khalid ${ }^{1 *}$, Shah Abdul Majid² and Mir Ajaz Akram³ $^{3}$
}

\begin{abstract}
Background: The possession of immense activities of the silver nanoparticles, due to which they have played an anomalous role in the various fields of bioscience, is of big concern of study in the recent era. So, the main aim of our study was to synthesize silver nanoparticles (AgNPs) using aqueous leaf extract of Ranunculus laetus using $0.1 \mathrm{M}$ silver nitrate solution, and the synthesized silver nanoparticles were tested for their antibacterial activity.

Results: The dark brown color of reaction mixture preliminary confirmed the synthesis of AgNPs. Further, characterization of synthesized silver nanoparticles showed UV-vis absorption peak at $442 \mathrm{~nm}$, infrared spectroscopy revealed nitro compounds and aromatic amines as reducing and capping agents while X-ray diffraction revealed face-centered cubic crystallites of AgNPs with an average size of $24.125 \mathrm{~nm}$. Scanning electron microscopy images confirmed spherical shape of silver nanoparticles with diameter $7.21-17.62 \mathrm{~nm}$. The synthesized silver nanoparticles revealed significant antibacterial activity $P<0.05$, against Escherichia coli (MTCC No. 739), Pseudomonas aeruginosa (MTCC No. 1688), Staphylococcus aureus (MTCC No. 96), and Bacillus subtilis (MTCC No. 441). The order of antibacterial potential was P. aeruginosa $>$ S. aureus $>E$. coli $>$ B. subtilis.
\end{abstract}

Conclusion: The ionic silver was reduced to silver nanoparticles by the action of reducing agents present in the aqueous leaf extract of Ranunculus laetus, and these nanoparticles bare credible antibacterial activity against diverse bacterial strains.

Keywords: Silver nanoparticles, Ranunculus laetus, UV-vis, X-ray diffraction, Scanning electron microscopy, Antibacterial activity

\section{Introduction}

Nanotechnology has evolved as a very fast-growing field with diverse applications in science and technology. Metal nanoparticles have engrossed the attention of scientist for their extraordinary physical and chemical properties (Garg 2012). In current years, nanomaterials have gained exceptional consideration due to their remarkable applications (Azizinezhad et al. 2014). An eco-friendly green mediated synthesis of the inorganic nanoparticle is a fast-growing research in the limb of nanotechnology (Sathya and Ambikapathy 2012). Due to simplicity and environment

\footnotetext{
* Correspondence: khalidbotanica@gmail.com

${ }^{1}$ Pest control and Ayurvedic Drug Research Lab, Vidisha, MP, India Full list of author information is available at the end of the article
}

friendliness, nanoparticle synthesis by the plant-mediated method has gained importance in recent years (Elumalai et al. 2010).

Among diverse nanomaterials, the popularity of silver nanoparticles has gained the attention of biologists, researchers, and scientists, due to their incredible physicochemical and natural characteristics (Li et al. 2014). Many study reports have shown that silver nanoparticle synthesis can be achieved by using root, leaf, seed, bark, and fruit as reducing agents (Kalidasan and Yogamoorthi 2014). Synthesis of silver nanoparticles by using plant extract has been explored by innumerable researchers, and the reports have revealed that these methods are quite simpler and nontoxic in contrast to physicochemical methods 
(Raja et al. 2012). Furthermore, silver nanoparticles have been used in the energy sector, sensing, electronics, and health care (Rycenga et al. 2011; Konop et al. 2016). From early times, the silver particles have been used as antimicrobial agents (Silver and Phung 1996). The silver nanoparticles have been verified as an efficient biocide against Gram-negative and Gram-positive bacteria (Jones and Hoek 2010; Anuj and Ishnava 2013).

In keeping view the importance of silver nanoparticles, the present study was carried out to elucidate the synthesis of silver nanoparticles using Ranunculus laetus leaf extract. The plant extract acts as reducing and capping agent, converting ionic silver to metal silver nanoparticles. Moreover, the antibacterial activity of synthesized silver nanoparticles using Ranunculus laetus leaf extract was evaluated against Escherichia coli, Pseudomonas aeruginosa, Staphylococcus aureus, and Bacillus subtilis bacterial strains.

\section{Materials and methodology}

\section{Plant collection and authentication}

Ranunculus laetus shoots were collected from the neighboring vicinity of Tehsil Lar district Ganderbal Jammu and Kashmir India during the month of August (2014). The plant was authenticated by Dr. Akhtar H. Malik (Curator, Centre for Biodiversity and Taxonomy, Department of Botany University of Kashmir). A voucher herbarium specimen was submitted to the Department of Taxonomy University of Kashmir bearing specimen number 2078- KASH for future references.

Ranunculus laetus is a perennial herb belonging to family Ranunculceae (Butter cup family) attaining a height of 30$70 \mathrm{~cm}$. The creeping rootstock possesses numerous fibrous roots and flowering stems. The leaves at the base have long petioles $(12-15 \mathrm{~cm})$ as the height of the plant increases, the size of the petioles decreases. So, the top leaves of the stem are sessile. The flowers are yellow in color with $17-25 \mathrm{~mm}$ diameter. The leaf paste of $R$. laetus is applied to affected parts of warts and wounds (Hanief et al. 2013) and for treating skin infection (Abbasi et al. 2010). Also, the plant decoction is used to cure indigestion (Rachna et al. 2012)

\section{Plant extract preparation}

Leaves of the plant were detached and washed with double distilled water until the foreign matter was removed. Then, the leaves were shade dried and grinded to powder with the help of electric grinder (Philips). Twenty grams of leaf powder was weighed by electric balance (Denver, Germany) and was placed inside of soxhlation apparatus (J-Sil, 50/42, Borosil glass). Ninety percent of ethanol was used as a solvent for extraction purpose. After $24 \mathrm{~h}$ of soxhlation, the crude extract was subjected to Vacuum Rotary Evaporator (Scientech) to obtain a semi-solid extract.
Table 1 Phytochemical investigation of ethanolic leaf extract of Ranunculus laetus

\begin{tabular}{|c|c|c|c|}
\hline \multicolumn{2}{|c|}{ Phytochemicals } & \multirow{2}{*}{$\begin{array}{l}\text { Tests } \\
\text { Molish's test }\end{array}$} & \multirow{2}{*}{$\frac{\text { R. laetus }}{++}$} \\
\hline Primary & Carbohydrates & & \\
\hline & & Fehling's test & ++ \\
\hline & & Barfoed's test & ++ \\
\hline & & Benedict's test & ++ \\
\hline & Amino acids & Ninhydrin test & ++ \\
\hline & & Biuret's test & - \\
\hline & & Millon's test & ++ \\
\hline \multirow{17}{*}{$\begin{array}{l}\text { Secondary } \\
\text { metabolites }\end{array}$} & Alkaloids & Mayer's test & - \\
\hline & & Wagner's test & ++ \\
\hline & & Hager's test & - \\
\hline & & Dragendroff's test & ++ \\
\hline & Terpenoids & Salkowski test & ++ \\
\hline & & Libermann-Burchards test & ++ \\
\hline & Flavonoids & Lead acetate test & ++ \\
\hline & & Alkaline reagent test & ++ \\
\hline & & Shinoda test & ++ \\
\hline & Tannins and phenolic & $\mathrm{FeCl}_{3}$ test & ++ \\
\hline & & Nitric acid test & ++ \\
\hline & & Gelatin test & - \\
\hline & & Dilute iodine solution test & - \\
\hline & Saponins & Froth test & ++ \\
\hline & Glycosides & Legal's test & ++ \\
\hline & & Keller-Killani test & - \\
\hline & & Borntrager's test & ++ \\
\hline
\end{tabular}

++ present, - absent

\section{Phytochemical investigation of crude extract}

The crude extract was tested for the presence or absence of phytoconstituents, carbohydrates, amino acids and proteins, alkaloids, terpenoids, glycosides, steroids, triterpenoids, flavonoids, saponins, and tannins according to the standard procedures (Trease and Evans 1989; Kokate et al. 2006).

\section{Synthesis of silver nanoparticles (Huang et al. 2011)}

Twenty milligrams of semi-solid extract was dissolved in $100 \mathrm{ml}$ of double distilled water in a beaker and was boiled for complete dissolution. The aqueous extract obtained was filtered through Whatman filter paper no. 1. For the synthesis of silver nanoparticles, take $10 \mathrm{ml}$ of aqueous plant extract and add to $90 \mathrm{ml}$ of silver nitrate solution $(0.1 \mathrm{M})$ in a beaker. The beaker was kept on a magnetic stirrer (Remi). After $10 \mathrm{~min}$, the color of the solution changed. For the stabilization of silver nanoparticles (AgNPs), the solution was kept as such for $24 \mathrm{~h}$. 


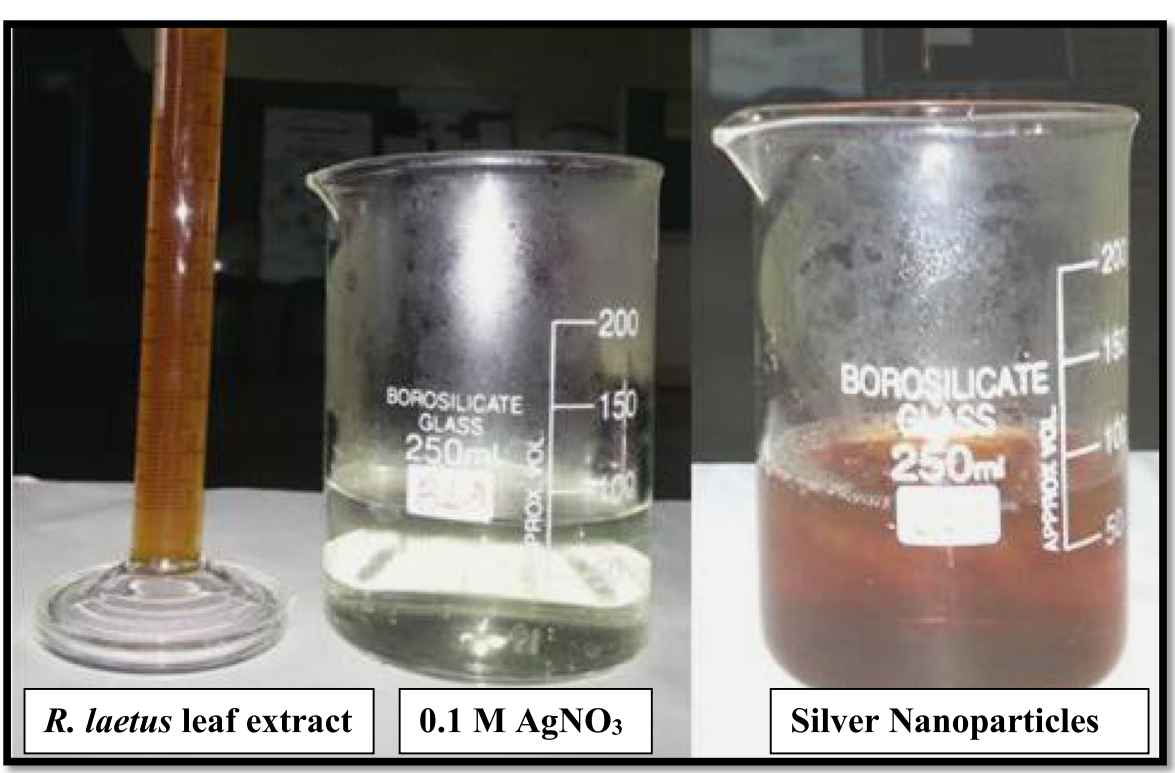

Fig. 1 Dark brown color of AgNPs

\section{Characterization of silver nanoparticles UV-vis spectroscopy}

The optical property of AgNPs was determined by double-beam UV-vis spectrophotometer (UV-vis Analyst- 0001, Electronic India). After the addition of $\mathrm{AgNO}_{3}$ to the plant extract, the spectrum was taken after $24 \mathrm{~h}$ between 300 to $700 \mathrm{~nm}$ using double distilled water as a blank.

\section{Fourier transformation infrared spectroscopy}

FTIR spectrometer (Shimadzu) was used for the analysis of synthesized AgNPs. The sample was prepared by dispersing the silver nanoparticles of leaf extract of Ranunculus laetus uniformly in a matrix of dry $\mathrm{KBr}$, compressed to form an almost transparent disc. $\mathrm{KBr}$ was used as standard to analyze the sample. The percentage transmittance of synthesized AgNPs was recorded in the range of $4000-400 \mathrm{~cm}^{-1}$.

\section{$X$-ray diffraction}

The shape and size of silver nanoparticle crystals were carried out by X-ray diffractometer (RIGAKU Japan Miniflex) equipped with $\mathrm{CuK} \alpha$ radiation $(0.154$ $\mathrm{nm}$ ) operated at a voltage of $30 \mathrm{kV}$ and $10 \mathrm{~mA}$ current. The sample was scanned in the region of $20^{\circ}$ to $80^{\circ}$ for $2 \theta$ at $0.04^{\circ} / \mathrm{min}$ scanning speed. The diffraction patterns of synthesized silver nanoparticles were obtained with the help of integrated X-ray powder diffraction software (PDXL). The average crystal size of synthesized silver nanoparticles was calculated by Debye-Scherrer equation:

$$
D=\frac{0.94 \lambda}{\beta \operatorname{Cos} \theta}
$$

Where $D$ is the crystallite size of AgNPs, $\lambda$ is the wavelength of the X-ray source $(0.1541 \mathrm{~nm}), \beta$ is the full width at half maximum of the diffraction peak, 0.94 is the Scherrer constant, and $\theta$ is the Bragg angle.

\section{Scanning electron microscopy}

The shape of synthesized silver nanoparticles was revealed by the scanning electron microscope (JEOL, Japan JSM 6390A). A thin film of the sample was prepared on a carbon-coated copper grid by dropping a very small amount of the sample on it, and the extra solution was removed by blotting paper. Then, the film on the SEM grid was allowed to dry by putting them under a mercury lamp for $5 \mathrm{~min}$. The sample was characterized at an accelerating voltage of 20 $\mathrm{kV}$, and a high-resolution image of the sample was obtained.

\section{Antibacterial activity}

Disc diffusion method and minimal inhibitory concentration The antibacterial activity of Ranunculus laetus-mediated silver nanoparticles was evaluated by KirbyBauer Disc diffusion technique (Bauer et al. 1966). Also, the minimal inhibitory concentration (MIC) of the synthesized silver nanoparticles was determined by spectrophotometric macrodilution method (Devienne and Raddi 2002). The antibacterial activity was carried out against Gram-negative bacteria Escherichia coli (MTCC No. 739) and Pseudomonas aeruginosa 


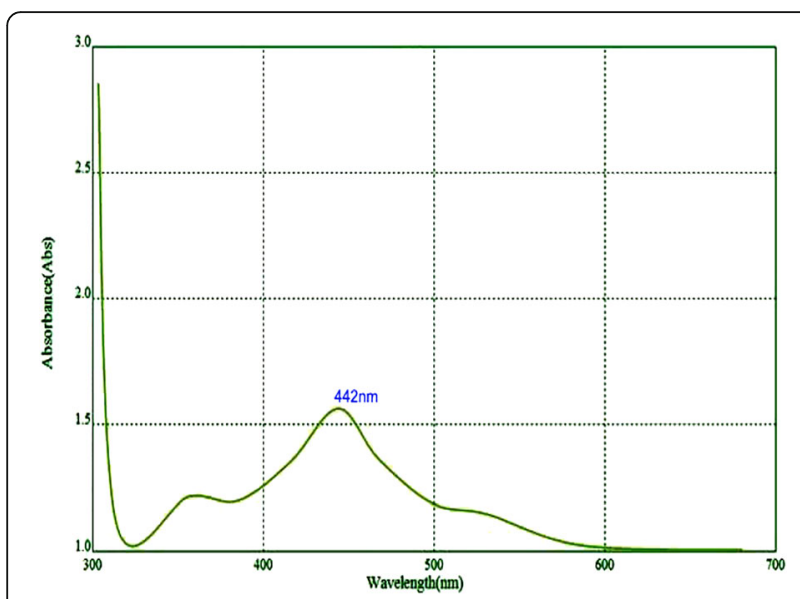

Fig. 2 UV-vis analysis of R. laetus-mediated AgNPs

(MTCC No. 1688), Gram-positive bacteria Staphylococcus aureus (MTCC No. 96), and Bacillus subtilis (MTCC No. 441).

\section{Results}

The results revealed that the Ranunculus laetus crude extract contained carbohydrates, amino acids and proteins as primary metabolites, and alkaloids, terpenoids, flavonoids, tannins and phenolic compounds, saponins, and glycosides as secondary metabolites as shown in Table 1.

The preliminary synthesis of silver nanoparticles was confirmed by the dark brown color of the mixture when the plant extract was added to $0.1 \mathrm{M} \mathrm{AgNO}_{3}$ solution (Fig. 1). Further characterization, done by UV-vis spectroscopy revealed surface plasmon peak at $442 \mathrm{~nm}$ of synthesized AgNPs which confirmed the synthesis of AgNPs (Fig. 2). The infrared analysis revealed two important peaks of $1339.61 \mathrm{~cm}^{-1}$ and $1228.92 \mathrm{~cm}^{-1}$ which corresponded to nitro compound $(\mathrm{N}-\mathrm{O}$ symmetric stretch) and aromatic amine (C-N stretch) respectively (Fig. 3). The X-ray diffraction pattern of our sample

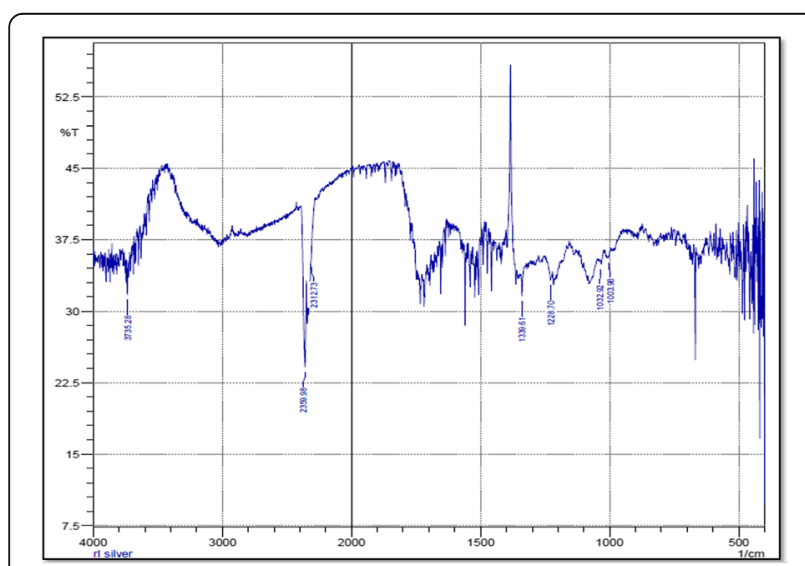

Fig. 3 Infrared analysis of R. laetus-mediated AgNPs

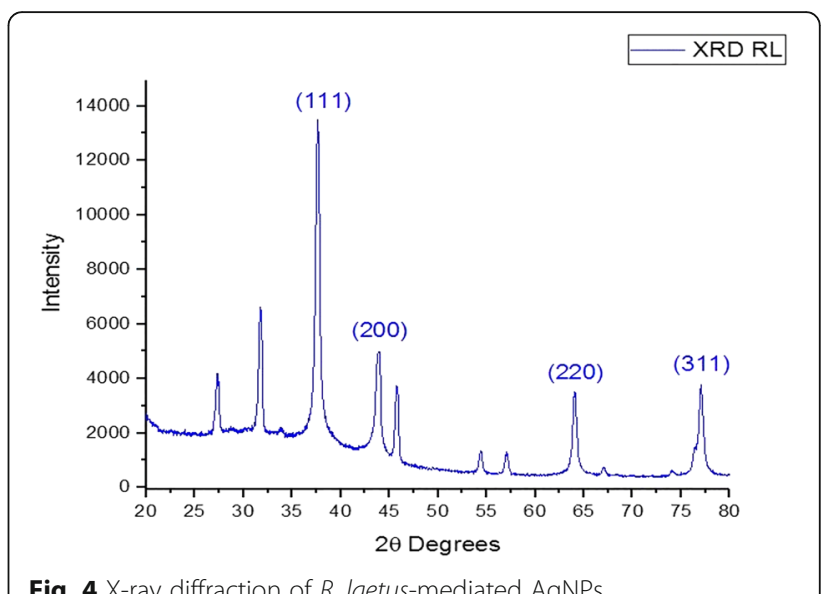

Fig. 4 X-ray diffraction of $R$. laetus-mediated AgNPs

was indexed with standard XRD spectrum of Joint Committee on Powder Diffraction Standards (JCPDS Card No. 53-61386). The XRD spectrum of Ranunculus laetus leaf extract-mediated AgNPs revealed four main 2 angle peaks at $38^{\circ}, 44.006^{\circ}, 64.057^{\circ}$, and $77.025^{\circ}$ (Fig. 4), which were indexed as 111, 200, 220, and 311 planes respectively, and correspond to the face-centered cubic lattice of the silver nanocrystals. Moreover, Ranunculus laetus leaf extract-mediated silver nanoparticle crystals revealed sizes between 17.65 and $39.79 \mathrm{~nm}$ with an average size of $24.125 \mathrm{~nm}$. The scanning electron microscopic image showed agglomeration, spherical shape, and the polydispersed nature of AgNPs, and the nanoparticles were $7.21-17.62 \mathrm{~nm}$ in diameter (Fig. 5).

Three different concentrations of Ranunculus laetus leaf extract-mediated silver nanoparticles, i.e., $100 \mathrm{mg} /$ $\mathrm{ml}, 50 \mathrm{mg} / \mathrm{ml}$, and $25 \mathrm{mg} / \mathrm{ml}$, were tested against E. coli, $S$. aureus, $P$. aeruginosa, and B. subtilis. Streptomycin $(100 \mathrm{mg} / \mathrm{ml})$ was used as a standard drug (Table 2). At $100 \mathrm{mg} / \mathrm{ml}$ concentration of $R$. laetus AgNPs, zone of inhibition (ZOI) against E. coli was measured $19.00 \pm$

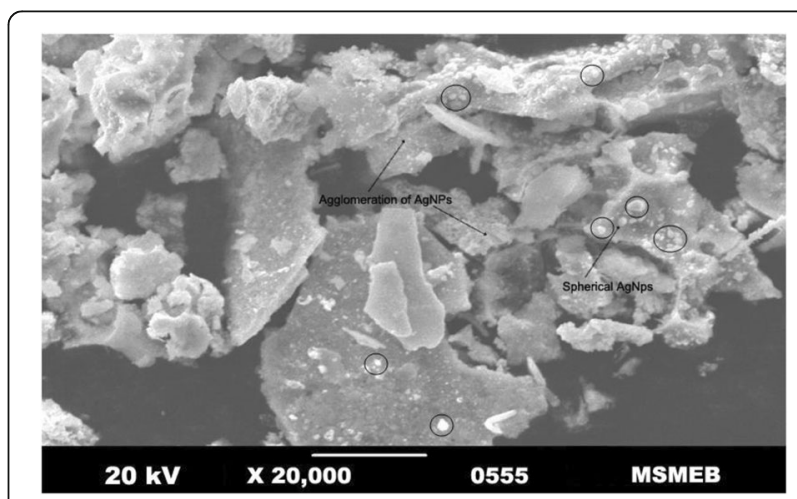

Fig. 5 SEM analysis of $R$. laetus-mediated AgNPs 
Table 2 Antibacterial activity of R. laetus-mediated AgNPs and leaf extract

\begin{tabular}{lllll}
\hline Concentration & E. coli & S. aureus & P. aeruginosa & B. subtilis \\
\hline $25 \mathrm{mg} / \mathrm{ml}$ AgNPs & $15.33 \pm$ & $15.66 \pm$ & $17.00 \pm$ & $12.66 \pm$ \\
& $4.61 \mathrm{~mm}$ & $2.51 \mathrm{~mm}$ & $1.73 \mathrm{~mm}$ & $0.57 \mathrm{~mm}$ \\
$50 \mathrm{mg} / \mathrm{ml}$ AgNPs & $16.33 \pm$ & $17.66 \pm$ & $18.66 \pm$ & $15.66 \pm$ \\
& $3.60 \mathrm{~mm}$ & $3.05 \mathrm{~mm}$ & $1.52 \mathrm{~mm}$ & $2.08 \mathrm{~mm}$ \\
$100 \mathrm{mg} / \mathrm{ml} \mathrm{AgNPs}$ & $19.00 \pm$ & $20.66 \pm$ & $22.00 \pm$ & $18.33 \pm$ \\
& $1.00 \mathrm{~mm}$ & $2.51 \mathrm{~mm}$ & $1.73 \mathrm{~mm}$ & $0.57 \mathrm{~mm}$ \\
R. laetus leaf extract & $12.33 \pm$ & $15.69 \pm$ & $17.12 \pm$ & $10.99 \pm$ \\
(100 mg/ml) & $0.34 \mathrm{~mm}$ & $0.47 \mathrm{~mm}$ & $1.30 \mathrm{~mm}$ & $0.61 \mathrm{~mm}$ \\
Streptomycin & $30.66 \pm$ & $30.66 \pm$ & $25.00 \pm$ & $28.00 \pm$ \\
(100 mg/ml) & $0.57 \mathrm{~mm}$ & $2.30 \mathrm{~mm}$ & $3.60 \mathrm{~mm}$ & $1.00 \mathrm{~mm}$ \\
\hline
\end{tabular}

$1.00 \mathrm{~mm}$ while $50 \mathrm{mg} / \mathrm{ml}$ and $25 \mathrm{mg} / \mathrm{ml} \mathrm{ZOI} \mathrm{were} \mathrm{mea-}$ sured $16.33 \pm 3.60 \mathrm{~mm}$ and $15.33 \pm 4.61 \mathrm{~mm}$ respectively as shown in Figs. 6 and 7. Standard streptomycin showed $30.66 \pm 0.57 \mathrm{~mm}$ ZOI against E. coli. Moving to $S$. aureus, the ZOI was measured $20.66 \pm 2.51 \mathrm{~mm}$, $17.66 \pm 3.05 \mathrm{~mm}$, and $15.66 \pm 2.51 \mathrm{~mm}$ against 100,50 , and $25 \mathrm{mg} / \mathrm{ml}$ concentrations respectively. while as, for the same strain streptomycin showed $30.66 \pm 2.30 \mathrm{~mm}$ ZOI. Furthermore, against $P$. aeruginosa, the zone of inhibitions was found larger than others. At 100, 50, and $25 \mathrm{mg} / \mathrm{ml}$ concentrations, the ZOI were calculated 22.00 $\pm 1.73 \mathrm{~mm}, \quad 18.66 \pm 1.52 \mathrm{~mm}$, and $17.00 \pm 1.73 \mathrm{~mm}$ respectively but streptomycin revealed $25.00 \pm 3.60 \mathrm{~mm}$ ZOI (Fig. 7). The R. laetus AgNPs at 100, 50, and $25 \mathrm{mg} / \mathrm{ml}$ concentrations showed $18.33 \pm 0.57 \mathrm{~mm}, 15.66 \pm 2.08 \mathrm{~mm}$, and $12.66 \pm 0.57 \mathrm{~mm}$ ZOI against $B$. subtilis while as for streptomycin, it was measured $28.00 \pm 1.00 \mathrm{~mm}$.

The $100 \mathrm{mg} / \mathrm{ml}$ of aqueous leaf extract of $R$. laetus showed ZOI of about $12.33 \pm 0.34 \mathrm{~mm}, 15.69 \pm 0.47 \mathrm{~mm}$, $17.12 \pm 1.30 \mathrm{~mm}$, and $10.99 \pm 0.61 \mathrm{~mm}$ against E.coli, S.aureus, $P$. aeruginosa, and B. subtilis respectively.

The MIC, determined by spectrophotometer macrodilution method was calculated by a sharp decline in the absorption value. The Ranunculus laetus AgNPs showed a MIC value of $1 \times 10^{-1} \mathrm{mg} / \mathrm{ml}$ against $E$. col; $1 \times 10^{0} \mathrm{mg} / \mathrm{ml}$ were recorded against $S$. aureus. Against $P$. aeruginosa, it was $1 \times 10^{-1}$ and $1 \times 10^{0} \mathrm{mg} / \mathrm{ml}$ was recorded against $B$. subtilis as shown in Table 3 .

\section{Discussion}

Various methods have been employed for the synthesis of nanoparticles which include physical, chemical, and biological methods. The physical and chemical methods involve the use of high temperatures, pressure, high current, a toxic substance like arsenic, sodium borohydride, hydrazine, and other chemical substance which possess very harmful and toxic implications (Ahmed and Ikram 2015). On the other hand, the biological method provides a very safe and easier method for nanoparticle synthesis with no side effects (Ahmad et al. 2011). Plants have been proven very efficient and alternative for the synthesis of nanoparticles in the past few decades (Bhati-Kushwaha and Malik 2013). Metal nanoparticles are synthesized by phytochemicals present in plants, which work as reducing and capping agents (Swarnalatha et al. 2013). For the synthesis of gold, silver, and gold-silver-copper alloy nanoparticles, plants have been exploited to a greater extent (Joerger et al. 2000; Sathishkumar et al. 2009). Our results revealed R. laetus leaf extract reduced the ionic silver into silver nanoparticles which were confirmed by UV-vis peak at $442 \mathrm{~nm}$. FTIR demonstrated the necessary compounds responsible for the reduction and stabilization of nanoparticles were nitro compounds and aromatic amines. Furthermore, XRD confirmed their crystalline nature with face-centered cubic lattice and SEM revealed their spherical shape. A similar type of results was found in the case of Eruca sativa and Spinacia oleracea-mediated AgNPs (Alaraidh et al. 2014),

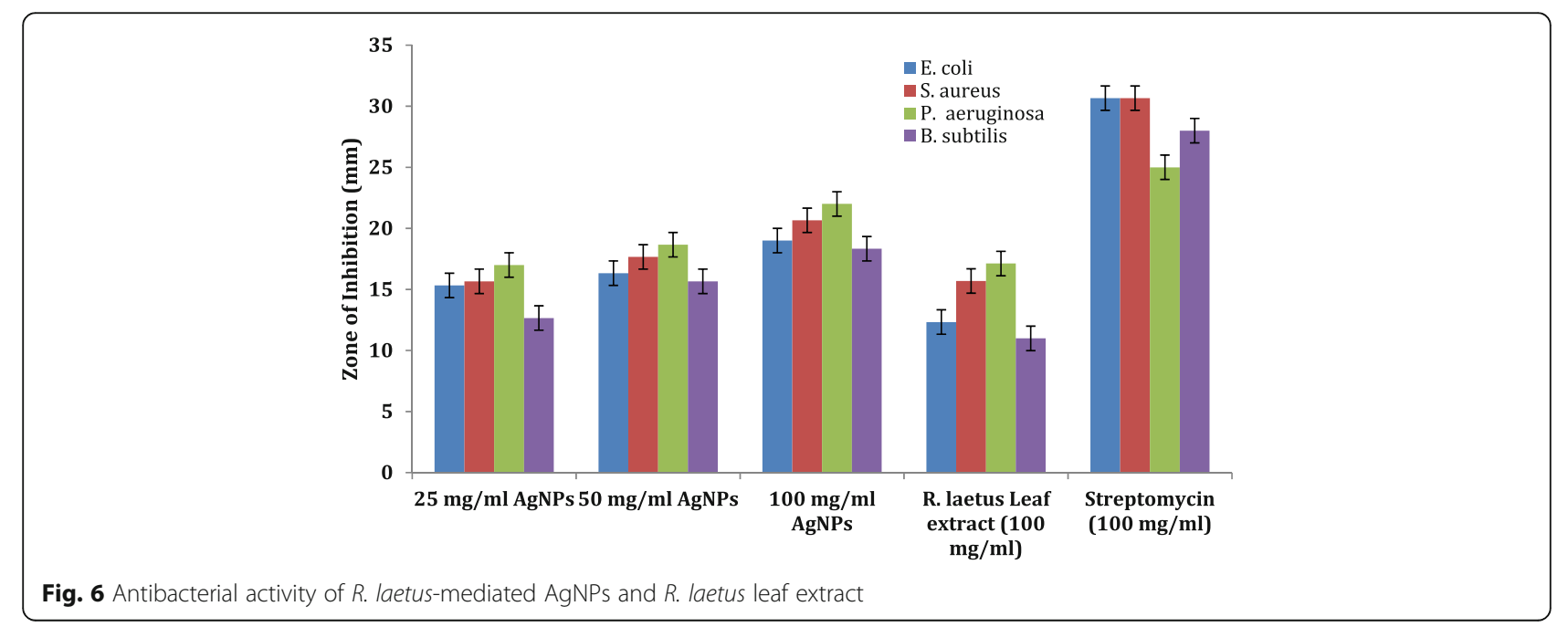



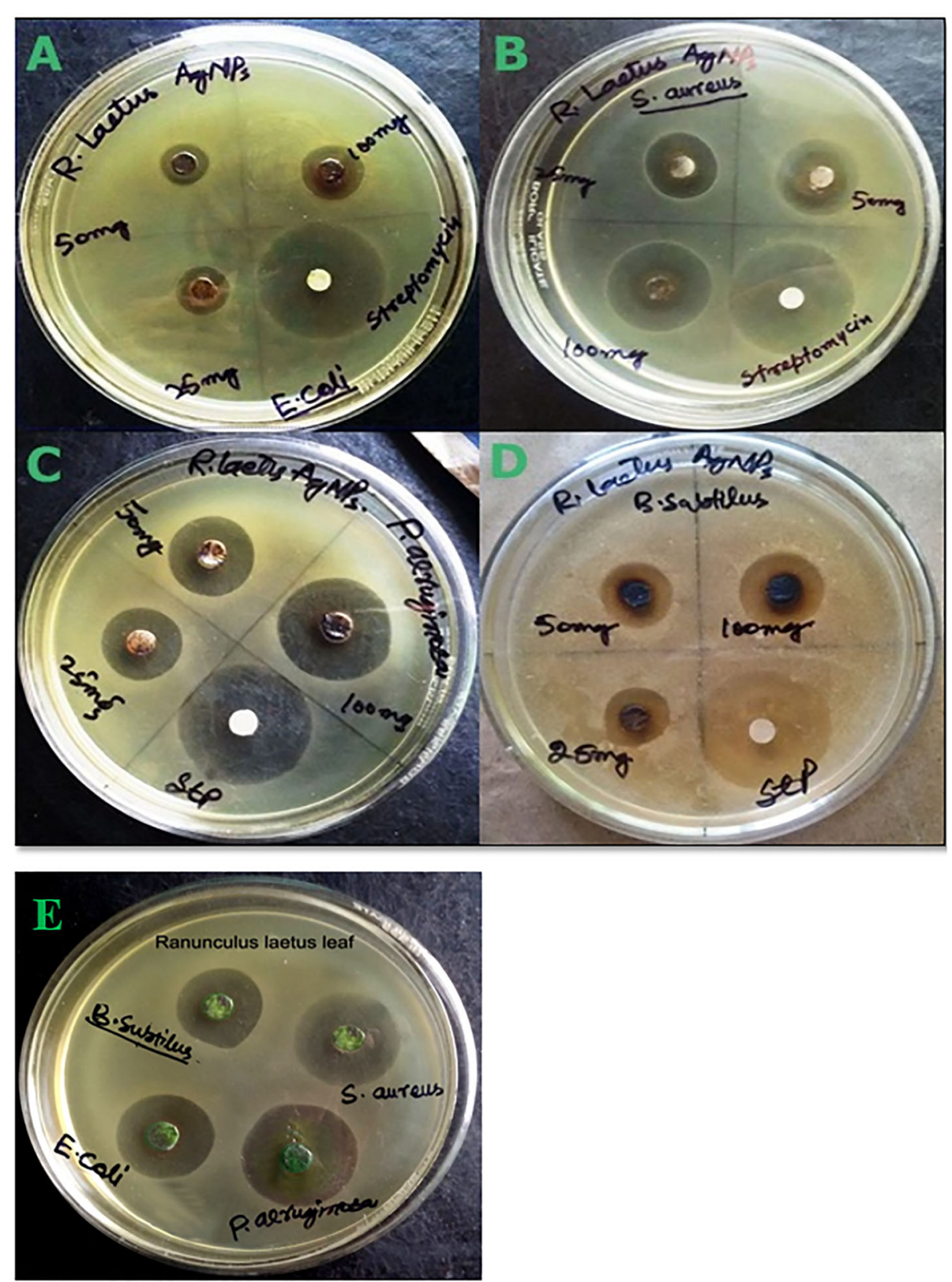

Fig. 7 R. laetus-mediated AgNPs. Zone of inhibition of against a E. coli, b S. aureus, c $P$. aeruginosa, $\mathbf{d} B$. subtilis, and e Antibacterial activity of $R$. laetus aqueous leaf extract

Table 3 MIC of R. laetus-mediated silver nanoparticles

\begin{tabular}{llllll}
\hline $\begin{array}{l}\text { Concentration } \\
(\mathrm{mg} / \mathrm{ml})\end{array}$ & $\begin{array}{l}\text { Absorbance }(\mathrm{nm}) \text { using } \\
\text { RL AgNPs E.coli }\end{array}$ & $\begin{array}{l}\text { Absorbance }(\mathrm{nm}) \text { using } \\
\text { RL AgNPs S. aureus }\end{array}$ & $\begin{array}{l}\text { Absorbance }(\mathrm{nm}) \text { using } \\
\text { RL AgNPs P. aeruginosa }\end{array}$ & $\begin{array}{l}\text { Absorbance }(\mathrm{nm}) \text { using } \\
\text { RL AgNPs B. subtilis }\end{array}$ & $\begin{array}{l}\text { Absorbance }(\mathrm{nm}) \text { using } \\
\text { streptomycin }\end{array}$ \\
\hline $1 \times 10^{-5}$ & $0.761 \pm 0.027$ & $0.798 \pm 0.061$ & $0.739 \pm 0.043$ & $0.381 \pm 0.032$ & $1.028 \pm 0.048$ \\
$1 \times 10^{-4}$ & $0.589 \pm 0.045$ & $0.641 \pm 0.037$ & $0.512 \pm 0.053$ & $0.307 \pm 0.029$ & $0.975 \pm 0.052$ \\
$1 \times 10^{-3}$ & $0.543 \pm 0.034$ & $0.487 \pm 0.027$ & $0.483 \pm 0.029$ & $0.262 \pm 0.032$ & $0.527 \pm 0.025$ \\
$1 \times 10^{-2}$ & $0.306 \pm 0.023$ & $0.426 \pm 0.049$ & $0.367 \pm 0.052$ & $0.215 \pm 0.058$ & $0.516 \pm 0.035$ \\
$1 \times 10^{-1}$ & $0.208 \pm 0.047$ & $0.355 \pm 0.051$ & $0.308 \pm 0.056$ & $0.179 \pm 0.023$ & $0.283 \pm 0.040$ \\
$1 \times 10^{0}$ & $0.197 \pm 0.020$ & $0.232 \pm 0.023$ & $0.252 \pm 0.038$ & $0.164 \pm 0.035$ & $0.247 \pm 0.028$ \\
$1 \times 10^{1}$ & $0.183 \pm 0.016$ & $0.204 \pm 0.061$ & $0.229 \pm 0.031$ & $0.128 \pm 0.021$ & $0.193 \pm 0.041$ \\
\hline
\end{tabular}


mulberry AgNPs (Awwad and Salem 2012) and Murraya koenigii AgNPs (Vinothkumar et al. 2014).

The smaller size of silver nanoparticles leads to augmented membrane permeability and cell damage (Ankanna and Savithramma 2011). Silver nanoparticles show electrostatic attraction with the bacterial cell membrane, which leads to the formation of pits on the cell surface and ultimately causes cell expiration (Sondi and Salopek-Sondi 2004). AgNPs cause the destruction or death of the bacterial cell by directly interfering with metabolic and growth signaling pathways by modulating tyrosine phosphorylation of putative peptide substrates critical for cell viability and division (Shrivastava et al. 2007). However, other mechanism revealed that silver nanoparticles cause the formation of free radicals which leads to cell death (Danilczuk et al. 2006). Our results showed that $R$. laetus-mediated silver nanoparticles possessed significant antibacterial activity $P<0.05$, against both Gram-positive and Gram-negative bacteria and the order of antibacterial activity was found $P$. aeruginosa $>S$. aureus $>E$. coli $>$ B. subtilis and the antibacterial activity is concentration dependent. Furthermore, the antibacterial activity of the synthesized silver nanoparticles is very much enhanced as compared with the leaf extract antibacterial activity. However, the MIC revealed the lowest concentration of $1 \times 10^{-1} \mathrm{mg} / \mathrm{ml}$ against E. coli and P. aeruginosa while against $S$. aureus and B. subtilis, it was $1 \times 10^{\circ}$ $\mathrm{mg} / \mathrm{ml}$. Our results were in compliance with antibacterial activity of AgNPs of Ocimum sanctum (Rout et al. 2011), Olea europaea (Awwad et al. 2012), and Withania somnifera (Anbalagan et al. 2016).

\section{Conclusion}

The present study was aimed to synthesize silver nanoparticles using Ranunculus laetus leaf extract and their antibacterial activity was also elucidated. Our results revealed that R. laetus-mediated AgNPs were synthesized. Also, the synthesized silver nanoparticles possessed potential with enhanced antibacterial activity against pathogenic bacteria as compared to the $R$. laetus aqueousleaf extract.

\section{Acknowledgements \\ This research work was supported by Pest Control and Ayurvedic Drug Research Lab, S.S.L. Jain P.G. College Vidisha, M.P. India.}

\section{Funding}

Not applicable

\section{Availability of data and materials}

The manuscript contained all the necessary data obtained during the study. However, on the recommendation or request addition information will be provided by the corresponding author.

\section{Authors' contributions}

The work was conceived and premeditated by SK, SAM, and MAA, and the experiment was conducted by SK. The data obtained was analyzed by SK, SAM, and MAA. The compilation of the first draft, as well as editing, was done by SK. The final manuscript was read and approved by all authors.
Ethics approval and consent to participate

Ethical approval had been granted by the Pest Control and Ayurvedic Drug Research Lab, S.S.L. Jain P.G. College Vidisha, M. P, bearing animal ethical committee registration number 804/03/ca/CPCSEA.

\section{Consent for publication}

Not applicable

Competing interests

The authors declare that they have no competing interests.

\section{Publisher's Note}

Springer Nature remains neutral with regard to jurisdictional claims in published maps and institutional affiliations.

\section{Author details}

${ }^{1}$ Pest control and Ayurvedic Drug Research Lab, Vidisha, MP, India.

${ }^{2}$ University of Kashmir, Srinagar, J\&K, India. ${ }^{3}$ Barkatullah University, Bhopal, $\mathrm{MP}$, India.

Received: 9 November 2018 Accepted: 18 January 2019

Published online: 01 February 2019

\section{References}

Abbasi AM, Khan MA, Ahmed M, Zafar M (2010) Herbal medicines used to cure various ailments by the inhabitants of Abbottabad district, North West Frontier Province, Pakistan. Indian J Tradit Knowl 9(1):175-183

Ahmad N, Sharma S, Singh VN, Shamsi SF, Fatma A, Mehta BR (2011) Biosynthesis of silver nanoparticles from Desmodium triflorum: a novel approach towards weed utilization. Biotechnol Res Int 2011:1-8

Ahmed S, Ikram S (2015) Chitosan \& its derivatives: a review in recent innovations. Int J Pharm Sci Res 6(1):14-30

Alaraidh IA, Ibrahim MM, El-Gaaly GA (2014) Evaluation of green synthesis of Ag nanoparticles using Eruca sativa and Spinacia oleracea leaf extracts and their antimicrobial activity. Iran J Biotech 12(1):1-6

Anbalagan S, Sankareswaran M, Prabhavathi P, Manikandan A, Karthikeyan G (2016) Green synthesis and characterization of Silver nanoparticles from Withania somnifera (L.) Dunal. Asian J Pharm Clin Res 9(5):34-39

Ankanna S, Savithramma N (2011) Biological synthesis of silver nanoparticles by using the stem of Shorea tumbuggaia Roxb. and its antimicrobial efficacy. Asian J Pharm Clin Res 4(2):137-141

Anuj SA, Ishnava KB (2013) Plant-mediated synthesis of silver nanoparticles using dried stem powder of Tinospora cordifolia, its antibacterial activity and its comparison with antibiotics. Int J Pharm Bio Sci 4(4):849-863

Awwad AM, Salem NM (2012) Green synthesis of silver nanoparticles by mulberry leaves extract. Nanosci Nanotechnol 2(4):125-128

Awwad AM, Salem NM, Abdeen MO (2012) Biosynthesis of silver nanoparticles using Olea europaea leaves extract and its antibacterial activity. Nanosci Nanotechnol 2(6):164-170

Azizinezhad F, Nasrollahil Z, Sadrnezhaad SK (2014) Synthesis of the silver nanoparticles with the using of Camomile plant. Eur J Exp Biol 4(2):124-127

Bauer AW, Kirby WMM, Serris JC, Turck M (1966) Antibiotic susceptibility testing by a standardized single disc method. Am J Clin Pathol 45:493-496

Bhati-Kushwaha H, Malik CP (2013) Biosynthesis of silver nanoparticles using fresh extract of Tridax procumbens Linn. Indian J Exp Biol 52:359-368

Danilczuk M, Lund A, Saldo J, Yamada H, Michalik J (2006) Conduction electron spin resonance of small silver particles. Spectrochim Acta Part A 63:189-191

Devienne KF, Raddi MSG (2002) Screening for antimicrobial activity of natural products using a microplate photometer. Braz J Microbiol 33:166-168

Elumalai EK, Prasad TNVKV, Hemachandran J, Therasa SV, Thirumalai T, David E (2010) Extracellular synthesis of silver nanoparticles using leaves of Euphorbia hirta and their antibacterial activities. J Pharm Sci \& Res 2(9):549-554

Garg S (2012) Rapid biogenic synthesis of silver nanoparticles using black pepper (Piper nigrum) corn extract. Int J Innov Biol Chem Sci 3:5-10

Hanief U, Mushtaq S, Khurshid S, Ishtiaq S, Ajaib M, Ulfat M (2013) Ethnobotanical studies on some wild plants of head Qadirabad and adjoining areas, Pakistan. Int J Phytomed 5:373-377

Huang H, Zhan G, Zheng B, Sun D, Lu F, Lin Y, Chen H, Zheng Z, Zheng Y, Li Q (2011) Biogenic silver nanoparticles by Cacumen platycladi extract: synthesis, formation mechanism and antibacterial activity. Ind Eng Chem Res 50:9095-9106 
Joerger R, Klaus T, Granqvist CG (2000) Biologically produced silver-carbon composite materials for optically functional thin-film coatings. Adv Mater 12(6):407-409

Jones CM, Hoek EMV (2010) A review of the antibacterial effects of silver nanomaterials and potential implications for human health and the environment. J Nanopart Res 12(5):1531-1551

Kalidasan M, Yogamoorthi A (2014) Biosynthesis of silver nanoparticles using Achyranthus aspera and its characterization. Int J Nanomate Biostruct 4(1):5-11

Kokate CK, Purohit AP, Gokhale SB (2006) Pharmacognosy, vol 14. Nirali Prakashan, New Delhi, pp 593-595

Konop M, Damps T, Misicka A, Rudnicka L (2016) Certain aspects of silver and silver nanoparticles in wound care: a mini-review. J Nanomater 2016:1-10

Li H, Xia H, Ding W, Li Y, Shi Q, Wang D, Tao X (2014) Synthesis of monodisperse, quasi-spherical silver nanoparticles with sizes defined by the nature of silver precursors. Langmuir 30(9):2498-2504

Rachna V, Vipin P, Dinesh K (2012) Ethno-medicinal uses of some plants of Kanag hill in Shimla, Himachal Pradesh, India. IJRAP 3(2):319-322

Raja K, Saravanakumar A, Vijayakumar R (2012) Efficient synthesis of silver nanoparticles from Prosopis juliflora leaf extract and its antimicrobial activity using sewage. Spectrochim Acta A Mol Biomol Spectrosc 97:490-494

Rout Y, Behera S, Ojha AK, Nayak PL (2011) Green synthesis of silver nanoparticles using Ocimum sanctum (Tulsi) and study of their antibacterial and antifungal activities. J Microbiol Antimicrob 4(6):103-109

Rycenga M, Cobley CM, Zeng J, Li W, Moran CH, Zhang Q, Qin D, Xia Y (2011) Controlling the synthesis and assembly of silver nanostructures for plasmonic applications. Chem Rev 111(6):3669-3712

Sathishkumar M, Sneha K, Won SW, Cho CW, Kim S, Yun YS (2009) Cinnamon zeylanicum bark extract and powder mediated green synthesis of nanocrystalline silver particles and its bactericidal activity. Colloids and Surf B 73(2):332-338

Sathya A, Ambikapathy V (2012) Studies on the phytochemistry, antimicrobial activity and green synthesis of nanoparticles using Cassia tora L. Drug invent Today 4(8):408-410

Shrivastava S, Beva T, Roy A, Sing G, Ramachandrarao P, Dash D (2007) Characterization of enhanced antibacterial effects of novel silver nanoparticles. Nanotech 18:1-9

Silver S, Phung LT (1996) Bacterial heavy metal resistance: new surprises. Annu Rev Microbiol 50:753-789

Sondi I, Salopek-Sondi B (2004) Silver nanoparticles as antimicrobial agent: a case study on E.coli as a model for Gram-negative bacteria. J Colloid Interface Sci 275:177-182

Swarnalatha Y, Krishnan D, Rajasekar SPV (2013) Antibacterial activity of biogenic silver nanoparticles from Sphaeranthus amaranthoides. Int J Pharm Pharm Sci 5(4):594-596

Trease GE, Evans WC (1989) Pharmacognosy, vol 13. Brailliar Tiridel Can MacMillan Publishers, pp 28-32

Vinothkumar K, Udayasoorian C, Jayabalakrishnan RM (2014) Biobase synthesis of silver metal nanoparticles using Murraya koenigii leaf extract. Int J Pure App Biosci 2(2):244-248

\section{Submit your manuscript to a SpringerOpen ${ }^{\circ}$ journal and benefit from:}

- Convenient online submission

- Rigorous peer review

- Open access: articles freely available online

- High visibility within the field

- Retaining the copyright to your article

Submit your next manuscript at $\boldsymbol{\nabla}$ springeropen.com 